\title{
IS THE WAR OVER? MEMORY AND OBSESSION IN J. G. BALLARD’S AUTOBIOGRAPHICAL WAR NARRATIVES
}

Pedro Groppo

Doutorando em Estudos Literários - UFMG

\begin{abstract}
RESUMO
A experiência de J. G. Ballard (1930-2009), que passou sua infância em Xangai durante a Segunda Guerra Mundial, influenciou a sua ficção de maneira marcante. Mesmo que a guerra tenha um papel proeminente no imaginário de Ballard, passaram-se quase quarenta anos até que ele escrevesse um romance semiautobiográfico, Império do sol. Ecos de suas experiências são comuns em suas obras, e certos eventos até são narrados mais de uma vez em diferentes contos e romances. Partindo de um desses eventos iterativos, o presente artigo analisa os principais textos autobiográficos e semiautobiográficos de Ballard de modo a elucidar a sua intrigante fusão de memória e imaginação.
\end{abstract}

\section{PALAVRAS-CHAVE}

Narrativas de guerra, autobiografia, trauma

J. G. Ballard's autobiography Miracles of life, published in 2007, finally confirmed what much of his fiction had been hinting at for quite some time: his childhood experiences in World War II have shaped deeply his imagination, and echoes of it are found everywhere in his fiction. Born in Shanghai to British parents in 1930, Ballard and his family were sent to the Lunghua interment camp, a few miles south of Shanghai along with many other international occupants of the city in 1942, following the attack on Pearl Harbor. Ballard spent the next three years in the camp, until the end of the war. After coming to England with his family in 1946, Ballard began writing his first short stories in the genre of science fiction. It took him another twenty years to return to Lunghua in his fiction with the publication of "The dead time" in 1977, although his work had been from the start permeated with gloomy, catastrophic and 
war-like imagery.

Common to many of Ballard's semi-autobiographical texts is the sense of uncertainty experienced by his fictional alter ego at the end of the war, the inability to return to the supposedly secure normalcy of peace. All of them narrate his leaving the camp into the no-man's land between Lunghua and Shanghai, in doubt whether the war had ended or World War III had just begun, with many overlapping elements. Two of the stories, "The dead time" and Empire of the sun, are fictions, told in the third person, with strong autobiographical elements. The latter is his most acclaimed and widely known book, which engaged his readers to identify the matrixes of many Ballardian icons, such as drained swimming pools and crashed planes, but at the same time holding a distance that denied autobiography as a key to his work. A sequel, The kindness of women, which Ballard calls "an autobiographical novel written with the full awareness of the fiction that that life generated during its three or four decades of adulthood", 1 is at the same time more autobiographical and more fictional, as his life is put into the context of his fiction. The account in Miracles of life is autobiographical and earnest, devoid of much of the "literariness" of the other texts. Ballard's non-fiction work, however, had already prefigured much of this material. "The end of my war", a piece published in the Sunday Times in 1995 and collected in A user's guide to the millennium, seems intent on differentiating Empire's Jim from his author.

In some countries, especially those in which Empire, because of its success, was the first Ballard book available in translation, Ballard is seen primarily as a war novelist. Even though his fiction does not deal with the subject directly apart from the two semi-autobiographical novels and a few short stories, ${ }^{2}$ the imagery of war is pervasive. War in fiction is often seen as a set of circumstances, a special and heightened reality that is extreme, excessive, unreal and distorted. Paradoxically, experiences gathered during this period are not seen as fanciful or unreal: war traumas are interpreted as an overdose of reality, an experience able to communicate and generate insights into human existence impossible to be acquired during times of peace. The veteran or the returned soldier is singled-out for his experience, incapable of fitting in, sporting the "thousand-yard stare" or scarred for having seen the horror at the heart of human nature. The unnatural, accelerated process of maturation produced by the

\footnotetext{
${ }^{1}$ SELF. Conversations: J. G. Ballard, p. 80.

2 Examples are “The killing ground” (1969), “Theatre of war” (1977) and “War fever” (1989).
} 
extraordinary set of circumstances has an incredible effect on the minds of those who took part in it. In other words, war can be a crash course on the real world, as one experiences too much in too short a time. War stories in a sense are not about war but about reality. This reading of war stories is intrinsically subjective, attentive to phenomenological experience, and often the battleground is psychological rather than political or social. The point of view of a child, as is the case of Empire, rather than an adult or even an active soldier in the conflict allows the narrative to be closer to this purely mental perspective. Unaware of the political implications, the child may be violently thrown into a situation in which he or she is not only passive, and even unequipped to understand.

\section{EMPIRE OF THE SUN}

Empire rests uneasily as a war bildungsroman, for Jim, the well-to-do child protagonist, is shown not to have matured at the end of the story, but rather to have grown old before his time, a subversion of the coming-of-age story. He becomes increasingly jaded and delusional, struggling to make sense of the confusing situation and his close contact to death. Ballard's texts take place in the protagonist's "inner space”, a phenomenological domain "where the inner world of the mind and the outer world of reality meet and fuse". ${ }^{3}$ This ever-mutable zone does not commit to either exterior or interior space; it is an imaginative fusion of both. It is not wholly psychological since the outer world appears equally informed by the individual's desires, and there is a constant slippage of one realm into the other. Even before the war, a synthesis between both spaces is present:

At night the same silent films seemed to flicker against the wall of his bedroom in Amherst Avenue, and transformed his sleeping mind into a deserted newsreel theatre. During the winter of 1941 everyone in Shanghai was showing war films. Fragments of his dreams followed Jim around the city (...) The whole of Shanghai was turning into a newsreel leaking from inside his head. ${ }^{4}$

Films feed his dreams, which in turn inform reality, a constant process of making reality ever more subjective. Jim's consumption of images and icons from movies, magazines, posters and ads is mentioned by David Punter as the consumption of "implanted icons"

\footnotetext{
${ }^{3}$ BALLARD. Introduction, p. 3. [0]

${ }^{4}$ BALLARD. Empire of the sun, p. 11, 14.
} 
and "discarded images", the true "points of reference against which our action takes place". 5 These representations suggest subjectivity, and, as Tamas Benyei argues, inner space is the end of intimacy as pure interiority as this reality is neither the external or the internal world, but a composite, a symptomatic product in which "there is a circulation of signifiers (...) traversing subjectivity as well, producing it and being produced by it". ${ }^{6}$ Empire is problematic as a subjective narrative because it rejects both external reality and interiority. Freud's proposition that dreams had to be analyzed for both their manifest and latent content, should be, according to Ballard, inverted in relation to the real world. This view allows the possibility of a system in which individuals are fully integrated into the social world, informing and being informed by a mesh of desire, memory, fantasy, and objects.

War in Empire disrupts this system and removes the boundaries between self and world. All is fine as long as the system does not interfere with one's body. Ballard describes the war in many instances as the moment in which he realizes reality is nothing but a stage set, ${ }^{7}$ something that can be pulled off from one's feet and completely change the rules from one moment to the other. Jim is thrown into a world of cognitive, social and existential estrangement, circled by "walls of strangeness", 8 a "peculiar space [that opens] around him, which separated him from the secure world he had known before the war". ${ }^{9}$ Benyei suggests that this estrangement is a necessary stage in his coming-of-age path, in which the old self makes way for the new, but somehow the transitional stage of death "does not seem to end", which indicates that he is already on the other side, at home. ${ }^{10}$ The stage of death not "wanting" to end is the critic's way of describing the terrifying sense of uncertainty experienced in the final part of the novel. In it, Jim leaves Lunghua only to roam in the deserted paddy fields of the noman's land between the camp and Shanghai, and during this section, he witnesses the deaths of some of his companions from camp. His mind reels as his body experiences extreme hunger and fatigue, and as more boundaries are broken, the narrative becomes even more surreal. If going into the war prompted Jim's mental and moral reeducation

\footnotetext{
${ }^{5}$ PUNTER. The hidden script: writing and the unconscious, p. 10.

${ }^{6}$ BENYEI. White Light: J. G. Ballard's Empire of the sun as a war story, p. 255.

${ }^{7}$ BALLARD. Miracles of life, p. 109.

${ }^{8}$ BALLARD. Empire of the sun, p. 50.

${ }^{9}$ BALLARD. Empire of the sun, p. 76.

${ }^{10}$ BENYEI. White Light: J. G. Ballard's Empire of the sun as a war story, p. 257.
} 
and abandonment of his lifestyle, he seems to have even more trouble in the transition between war and peace. In a sense, Jim's coming-of-age during the years of war does not seem to have made him into a more mature human being, only a troubled one, a notion that is explored in Kindness. In Empire there is mention to a doubling of his self, a mental construct that allows Jim to be buoyant: "It was his mirror self who felt faint and hungry."11 Jim has adapted very well to his life in Lunghua but this adaptability, Andrzej Gasiorek writes, comes at a heavy price:

It depends on the power of a saving imagination, which enables him to fill his mind with evasive dreams, but it relies on a numbing of affect, which permits him to accept the inverted values of camp life as normal. ${ }^{12}$

When a Chinese coolie is brought to the center of the camp and is beaten to death, Jim is more preoccupied with reading one of his magazines and studying: "He would have liked to leave but all around him the prisoners were motionless as they watched the parade ground (...) Jim thought about his algebra prep."13 His reaction is one of complete disconnect and denotes his inability to respond emotionally to an act of murder, a distancing that the war had taught him in order to protect himself, but one he cannot seem to negotiate. The image of a Chinese peasant being tortured to death by Japanese soldiers is a recurring one, told in Kindness and Miracles as part of his walk back to Shanghai, taking place in a railway station and requiring the character to ignore the act of violence, numbing his affect. Jim's obsession with death begins soon after this event, and he questions many adults as to the existence of the soul and the moment it might leave the body, clearly an attempt to have some sort of security in one area pertaining to death. At one point, Jim wonders if "perhaps his soul, instead of leaving his body, had died inside his head". ${ }^{14}$ After seeing the white light of the atomic bomb at the Olympic Stadium during the march up-country, Jim imagines the white light as "a premonition of his death, the sight of his small soul joining the larger soul of the dying world", ${ }^{15}$ which indicates his vision of death as an end not only to suffering, but of subjectivity.

\footnotetext{
${ }^{11}$ BALLARD. Empire of the sun, p. 103.

${ }^{12}$ GASIOREK. J. G. Ballard, p. 147.

${ }^{13}$ BALLARD. Empire of the sun, p. 255.

${ }^{14}$ BALLARD. Empire of the sun, p. 273.

${ }^{15}$ BALLARD. Empire of the sun, p. 267.
} 
Perhaps it is precisely this disconnect between two halves of his self that troubles Jim so. One is the helpless boy from Shanghai, who cries for his parents, while the other is the cynical boy whose soul has perhaps died inside his own body, and who would even not recognize his parents if he saw them. "The war had lasted for too long. At the detention centre, and in Lunghua, he had done all he could to stay alive, but now a part of him wanted to die. It was the only way in which he could end the war."16 The white light of the atom bomb might signify a welcome end to his overloaded mind and his subjectivity, as the bomb takes a while to be interpreted as such by Jim. At first, he thinks the sun blinked, and only after consulting with someone else does he understand that it was a weapon designed to end the war. What Jim experiences is not the end, but rather the start of a new interstitial stage, unbounded by the rules of neither peace nor war; a stage he imagines must be World War III, one marked by the atomic fallout - a fictional space in which all of Ballard's fiction takes place, in a sense. The bomb presents also a significant blow to Jim's psyche, as it does not fit into the images that populated his imagination fed from magazines, movies, and newsreels and which he expected, such as airplanes, soldiers, tanks and ships. The atom bomb and its unclassifiable, uncanny white light remains outside Jim's frame of reference, outside his vocabulary. The central struggle of the book, suggests Gasiorek, is between Jim's comprehension of the events and his attempt to discover a vocabulary adequate to his experiences. ${ }^{17}$ Ballard is aware of that, and the text possesses a Bakhtinian doublevoiced discourse, defined by Simon Dentith as one in which the reader can recognize that there are two distinct consciousnesses operating in a single utterance, and that their evaluative attitudes are not the same. ${ }^{18} \mathrm{Jim}$ is often portrayed in situations as, because of his innocence and overactive imagination, much more adaptable and buoyant than the older and more mature characters.

Death, during the final stages of the war, is pervasive in Jim's life, and he becomes increasingly delirious during his long walk to Shanghai. Eventually he is brought back to camp, now dominated by British bandits, and is later picked up by Dr. Ransome, one of the inmates at Lunghua, and taken to a hospital in Shanghai. Unlike in Kindness and Miracles, he does not complete the journey to his home. At one point,

\footnotetext{
${ }^{16}$ BALLARD. Empire of the sun. p. 266.

${ }^{17}$ GASIOREK. J. G. Ballard, p. 150.

${ }^{18}$ DENTITH. Parody, p. 64.
} 
however, Jim has become so disconnected from reality that he is certain that food "feeds death", and when he encounters the body of a young kamikaze pilot (whom before he had identified with), he tries, unsuccessfully, to resuscitate him. The food in his mouth seems alive and writhing, and the living began to resemble the dead. The attempted resuscitation of the pilot, rendered in Steven Spielberg's film version of Empire, underscores Jim's double self as he is shown trying to resuscitate his younger self, still wearing his old Catholic school uniform. Jim's mental state then is severely perturbed, showing signs of schizophrenia and psychosis. The idea of the dead feeding off the living, a notion that accentuates the overpowering force of death, is also present in "The dead time”.

\section{“THE DEAD TIME”}

The unnamed protagonist of this 1977 short story ${ }^{19}$ is a twenty-year old inmate of a Japanese camp outside Shanghai during the final weeks of World War II. He is older than any of the protagonists of the other narratives, probably because the major plot point involves he and a couple of other inmates having to transport, in some trucks, dead bodies to a cemetery in Soochow, north of Shanghai. The story takes place after the bombing of Hiroshima and Nagasaki and during the "dead time” before peace, and the inmates are to be released as long as they deliver the bodies to the cemetery.

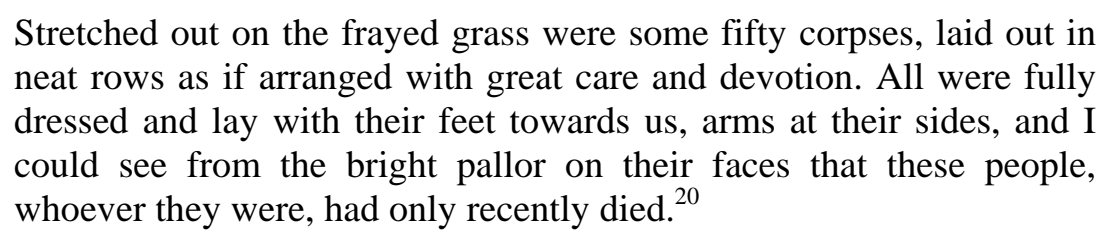

This task requires an act of numbing of affect, something that Ballard associates with this period shortly after the war. Despite the initial surprise, they engage in the task and load the corpses into the truck. ${ }^{21}$ The corpses, the narrator notices, are much better fed than he and any of his mates were. Their bodies showed no signs of violence, which for

\footnotetext{
${ }^{19}$ First published in the magazine Ambit, later collected in 1982's Myths of the near future.

${ }^{20}$ BALLARD. The dead time, p. 147.

${ }^{21}$ The story recalls Henri-Georges Clouzot's 1953 film The wages of fear (itself based on a book by Georges Arnaud) in which four men are hired to transport in two trucks a load of nitroglycerine to extinguish the fire on an oil well, a job considered too dangerous for their syndicated employees. The drivers are inexperienced and are to carry extremely sensitive and deadly material.
} 
him could well mean an epidemic, but this detail adds to the oneiric atmosphere of the story, in which the corpses might well be an allegory for ordinary people, people who have not been prisoners in these concentration camps. A distance is put between the narrator and the bodies, as if handling them was "a kind of forced intimacy that absolved [him] from all future contact or obligation”. ${ }^{22}$ Moreover, there is an uncertainty toward these bodies, one that is echoed in Empire: when do they stop being human beings and become objects? Do they ever? When one of the trucks fails, the characters are required to lighten the load, so they dump some of the bodies in a river, rationalizing that the Japanese could not have been serious. Some time later the bodies clog up a passage, and the protagonist is surprised to recognize each of them, a "presentiment of death - though not [his] own or of these drowned creatures" ${ }^{23}$ - takes over him. As the bodies are retrieved and handled even more, he sees for the first time a "distinct personality" in the face of one of them, a woman, "visualizing her talking” to him. The more the bodies are dealt with, the harder it gets to consider them mere objects, a rather paradoxical view since their appearance worsens with time. In fact, the protagonist starts to see it as a mission, and guards the completeness of his truck's bodies calling it his "flock" and removing the ones mistakenly taken from his companion Hodson's truck, seen as “intruders, (...) members of a rival clan”. ${ }^{24}$ Clearly, he has begun to create meaning even in death, a certain sense of security, "loyalty" and "the feeling that they, the dead, were more living than the living who had deserted [him]". ${ }^{25}$ Like Jim, he is delirious from hunger and imagines he is "the instrument of the new order (...) delegated by [the dead] to bring to the world,” and soon the whole planet would "share in the new life they had earned for us". ${ }^{26}$ Food is suddenly no longer important, only a spiritual form of nourishing that only death can provide.

This notion of repopulating the world with cadavers ${ }^{27}$ can be seen as a metaphor for the post-war world in the shadow of the atomic fallout. Dominika Oramus writes that contemporary reality in Ballard's fiction is post-apocalyptic: "though we are not literally living amidst the ruins, the golden age is far behind us and we are witnessing

\footnotetext{
${ }^{22}$ BALLARD. The dead time, p. 150.

${ }^{23}$ BALLARD. The dead time, p. 154.

${ }^{24}$ BALLARD. The dead time, p. 157.

${ }^{25}$ BALLARD. The dead time, p. 158.

${ }^{26}$ BALLARD. The dead time, p. 161.

${ }^{27}$ An idea from Ballard's High-rise (1975).
} 
the twilight of the West". ${ }^{28}$ It is a world shadowed by the irreconcilable recognition of the human propensity for self-destruction, where total annihilation is possible. To grasp this logic of the dead, the allure of the inorganic and inhuman, as well as the Freudian death-drive, must be understood. This metaphor is also a way of embracing the inevitability of death, so close to the protagonists of Empire and "The dead time". The idea that the dead could take over the world conceptually is a way of deflecting their own mortality, a mental distortion that effaces subjectivity, and, like the bomb, brings about "total fusion and non-differentiation of all matter", ${ }^{29}$ a comforting thought that eliminates guilt and the anxiety of these strained situations. Death and the lack of subjectivity would be the ultimate relief, a resolution to this uncertain and unstable “dead time.” Carrying a starving Chinese girl in his arms, the protagonist, without thinking, gives her a morsel of his own flesh for her to eat. Instead of letting her die on her own, he leads her, with an Eucharist of his own body, into his flock, harnessing the power of the dead to move into a mental domain that transcends it: "At last, through this child and my body, the dead were coming to life, rising from their fields and doorways and coming to greet me (...) I had given my death to them and so brought them into this world". ${ }^{30}$ This happens as they arrive at the Soochow camp, where his parents are supposed to be, and it raises the question whether this is all a preparation, a mental delusion for the recognition of the bodies of his own parents, this being a way for him to be reunited with them. Only then is he is able to say, "I knew now that the war was over". 31

\section{THE ATROCITY EXHIBITION}

The first appearance of Shanghai or a more overt autobiographical bent in Ballard's fiction dates to 1966, with the story "The atrocity exhibition". ${ }^{32}$ In the texts that comprise the book of the same name, Ballard's fictional stand-in is the Traven character (who recurs as Tallis, Travis, Talbot, and Trabert), a man suffering from

\footnotetext{
${ }^{28}$ ORAMUS. Grave new world, p. 12.

${ }^{29}$ BALLARD. The atrocity exhibition, p. 48.

${ }^{30}$ BALLARD. The dead time, p. 163.

${ }^{31}$ BALLARD. The dead time, p. 163.

${ }^{32}$ Other stories from The atrocity exhibition that mention Shanghai and World War 2 are "The great American nude" (1967), "The University of Death" (1968), and "Tolerances of the human face” (1969).
} 
severe psychological fragmentation, a symptom that the stories mirror in their structure and narrative. In the 1966 story, Travis listens to "secret transmissions" from an unspecified place, one of which recalls Shanghai in 1945:

V.J.-Day, ${ }^{33}$ the bodies of Japanese troops in the paddy fields at night. The next day, as he walked back to Shanghai, the peasants were planting rice among the swaying legs. Memories of others than himself, together these messages moved to some kind of focus. ${ }^{34}$

Atrocity is one of Ballard's most complex texts, a collection of interrelated short stories or "condensed novels"; a collage, a narrative woven out of found texts, the reinterpretation of reality in terms of the reconfiguration of central elements to evoke an inversion of the inner and outer world. Gasiorek describes it as a text that works by way of "suggestions, resonances, echoes", 35 and is almost an index of Ballardian icons, themes, and concerns. Traven, haunted by his wartime experiences and by the death of his wife, is on a quest for meaning. ${ }^{36}$ The war, for Traven had become

an expression of the failure of his psyche to accept the fact of its own consciousness, and of his revolt against the present continuum of time and space. (...) $[\mathrm{H}]$ is intention is to start World War III, though not, of course, in the usual sense of the term. The blitzkriegs will be fought out on the spinal battlefields, in terms of the postures we assume, of our traumas mimetized in the angle of a wall or balcony. ${ }^{37}$

He believes that by enacting certain bizarre experiments the patients will reconfigure the relation between self and world, embodying a sort of "secularized apocalyptic urChrist $^{38}$ figure who seeks to redeem the world". ${ }^{39}$ In a sense, Ballard and his characters are traumatized by the war, and the act of writing, as well as Traven's experiments, is a therapeutic attempt to exorcize these ghosts. More radically, it is an attempt to reconfigure and reinterpret the world according to their own needs, revealing that their

${ }^{33}$ Victory over Japan Day (V-J Day) is the day Japan announced its surrender, effectively ending World War II, on August 15, 1945.

${ }^{34}$ BALLARD. The atrocity exhibition, p. 5.

${ }^{35}$ GASIOREK. J. G. Ballard, p. 59.

${ }^{36}$ Ballard's wife, Mary, died in 1964 of pneumonia, leaving him with three kids to raise. He said Atrocity was written to make sense of the irrational world he was living in.

${ }^{37}$ BALLARD. The atrocity exhibition, p. 6.

${ }^{38}$ Christ figures abound in Ballard's work, in "The dead time," in The unlimited dream company, for instance. The most famous one is Vaughan in Crash, who dies heroically (or pathetically) in a symbolic collision with Elizabeth Taylor's limousine.

${ }^{39}$ GASIOREK. J. G. Ballard, p. 60. 
selves are unflinching, as it is the world that must be rewritten in their own fashion.

This confusion between self and world is later raised in Kindness: to what extent is Atrocity an accurate cultural diagnosis rather than a purely subjective projection? Kindness implies that the latter is a more accurate view, as Peggy, Jim's friend from the camp, points out to him: "the Vietnam war, the Kennedy assassination, the Congo, those ghastly ratissages (...) might have been invented for you”, while he concedes that in "many ways the media landscape of the 1960s was a laboratory designed specifically to cure me of all my obsessions". ${ }^{40}$ In the end, Jim's concern, apparent in Empire, of the end of subjectivity and integration into the landscape, a fusion with other real and cultural bodies, is effected to the point that the character's psyche, and the meaning of Ballard's fiction, are thrown into an interstitial zone. The question of whether Traven is a doctor or a patient is raised in the text of Atrocity, which can be also asked in the case of Ballard. Is he a doctor, appropriately diagnosing the malaises of our culture and society, or is he a patient, only resolving his traumatic experiences?

\section{THE KINDNESS OF WOMEN AND MIRACLES OF LIFE}

The sequel to Empire has been sometimes described as a collection of interconnected, sequential short stories, since every chapter deals with one stage of the protagonist's life and is self-contained. The third chapter, “The Japanese soldiers”, goes back to the moment of uncertainty, previously written about in Empire and "The dead time,” when the guards at Lunghua disappear. "By leaving the camp I had stepped outside my own head. Had the atom bombs in some way split the sky and reversed the direction of everything?”, 41 he wonders, eventually deciding to walk the eight miles back to Shanghai. This portion of the narrative resembles little that of Empire, with this Jim narrating it clearly and soberly, a contrast from the delirious experiences of the former book. On a railway station, he sees four Japanese soldiers, fully armed, waiting. One of them signals to Jim as he walks by, beckoning him to come closer. Jim is surprised to find out that one of the soldiers holds a telephone wire, which is coiled around the neck of a young Chinese man. The Chinese is out of place, "unlike the soldiers and myself”, and Jim struggles to keep his composure. He knows he is not supposed to comment or acknowledge what is happening or even oppose them; he tells

\footnotetext{
${ }^{40}$ BALLARD. The kindness of women, p. 289, 190.

${ }^{41}$ BALLARD. The kindness of women, p. 46.
} 
himself the Chinese is an important prisoner, to protect himself from the realization that he is just an innocent man. Jim stays there, unable to leave, in a sort of "dead time", in which no new development takes place: the Chinese is still being choked, the Japanese are still, and Jim is uneasy, trying to talk and explain that the war is over, but he does not know enough of the language, and his eyes keep going back to the Chinese. "From the moment I left Lunghua all the clocks had stopped. Time had suspended itself". ${ }^{2}$ This stilted moment seems to take forever, with Jim sharing a sweet potato with one of the Japanese, them subtly harassing him and asking for his transparent plastic belt. One of the soldiers inspects the belt, carefully testing the plastic between his hands, and destroys it, as the Chinese is finally killed. "None of them had been touched by the youth's death, as if they knew that they too were dead and were matter-of-factly preparing themselves for whatever end would arrive out of the afternoon sun". ${ }^{43}$ As in “Dead time”, imagining that one's self and the whole world are dead, joining in death, is a way of justifying the death of affect so as to cope with the close contact of the reality of death.

For the first time it seemed obvious that this remote country platform was the depot from which all of the dead of the war had been dispatched to the creeks and burial mounds of Lunghua. The four Japanese soldiers were preparing us for our journey. I and the Chinese whom they last suffocated were their last arrivals, and when we had gone they would close the station and set out themselves. ${ }^{44}$

Jim talks as if he was already dead, the only way conceivable to him that this event could ever make sense. Upon returning to Shanghai, he finds hard to resume his old life, as if "landed in an unfamiliar future", relating in traumatic terms, "so much had happened that I had not been able to remember or forget”, and he feels his sense of self changed, as if he had "mislaid part of [his] mind somewhere between Lunghua and Shanghai”. ${ }^{45}$ Describing the event to his friend Peggy, Jim feels disappointed he did not stay behind with the Japanese, as if, in a way, he wanted the security they could have provided him in their ushering towards death.

Kindness problematizes memory and the imagination in ways that Empire does not. Jim's "entire world had been shaped by the camp," and "instead of wanting to

\footnotetext{
${ }^{42}$ BALLARD. The kindness of women, p. 55.

${ }^{43}$ BALLARD. The kindness of women, p. 56.

${ }^{44}$ BALLARD. The kindness of women, p. 56.

${ }^{45}$ BALLARD. The kindness of women, p. 60.
} 
escape from it", he had sought "to burrow ever more deeply into its heart", ${ }^{46}$ and in a sense the main theme of the book is Jim's failure to work through personal trauma and the difficulty in living in an unresolved psychological limbo. His psychological death, symbolized by the death of the Chinese, is eventually undone by a life-saving rebirth, but more than thirty years and most of the book take place in between. The murder of the Chinese had been to him a vicarious experience of his own death, an experience that needed to be replayed, as Peggy points out: “A part of it actually happened to you. All those car crashes and pornographic movies, Kennedy's death, they're your way of turning it into a film, something violent and glamorous". ${ }^{47}$ This identification is such that Jim's mind is "up there, molded against the screen". ${ }^{48}$ Gasiorek argues that by rendering it safe and displacing the violence to the realm of the imaginary, he ends up by colonizing his psyche to the glamorized allure the violence subsequently represents. ${ }^{49}$ And in fact, Jim's “cure” would be prompted by seeing the film of Empire for the first time in the chapter that closes the book, a complex act of identification with a mixture of imagination, remembrance and critical distance.

In Miracles, the episode is strikingly close to the one narrated in Kindness. Ballard writes of the moment of uncertainty: “August 1945 formed a strange interregnum when we were never wholly certain that the war had ended, a sensation that stayed with me for months and even years. ${ }^{, 50}$ Walking towards the railway station, he is aware of a singsong (absent in Kindness but not in Empire), which turns out to be the Chinese on his knees, being strangled by Japanese soldiers. One of the soldiers calls Ballard up and asks to see his transparent plastic belt, "a prized novelty that no Japanese was likely to have seen", ${ }^{1}$ and examines it slowly, while Ballard waits and the Chinese is being choked to death. There is a great disconnect between the murder taking place and the matter-of-fact manner of the Japanese, who act as if "beyond the point where life and death meant anything at all ${ }^{52}$ and demand Ballard to act the same way. Ballard continues describing the in-between world where wars merged into one another, and the

\footnotetext{
${ }^{46}$ BALLARD. The kindness of women, p. 48.

${ }^{47}$ BALLARD. The kindness of women, p. 270.

${ }^{48}$ BALLARD. The kindness of women, p. 269.

${ }^{49}$ GASIOREK. J. G. Ballard, p. 150.

${ }^{50}$ BALLARD, Miracles of life, p. 103.

${ }^{51}$ BALLARD. Miracles of life, p. 106.

${ }^{52}$ BALLARD. Miracles of life, p. 107.
} 
proximity of his autobiography to his fictional narratives calls into question how much of Miracles are actually memories, unadorned and uninformed by decades of filtering these memories through his imagination. While not questioning the authenticity of Ballard's remembrances, they seem too close to fiction - his autobiography having been told in so many ways, displaced in so many troubled characters and alien settings that the text purported to be the truth does not sound any truer; only another version, even if the most earnest one. His experience of the war, Ballard reiterates in Miracles and the autobiographical essay "The end of my war", is no different from that of millions of teenage boys in occupied Europe or Asia. We read his fiction not for his experiences, but for his imagination and the way these events have shaped them, into his powerful literary creations.

\section{FINAL REMARKS}

The temptation to read and decode Ballard's fiction according to this autobiographical key is hard to resist: the Lunghua interment camp would be the Ballardian model for social environment. An enclosed space with special rules and codes where "existence shades inevitably into a slow decline unto death" is the model for the high-rises, gated communities and science parks of Ballard's fiction: "places to rebel against, if space can be found; a space to escape from, if escape is possible". ${ }^{53}$ His fiction is one of repetition, of reworking of familiar imagery and material, a repetition that does not denote so much lack of ideas but a symptomatic obsession, a need to articulate a consistent and particular view of the world.

In an essay titled “Time, memory and inner space”, Ballard touches on the subject of the landscapes of one's childhood influencing the writer's imagination, using the case of flooded Shanghai and his novel The drowned world. Ballard's Freudian theory of creative writing is summarized in this essay, with the writer selecting images and ideas that reflect the "internal landscapes of his mind", to which the "dream worlds" invented by the writer are "external equivalents of the inner world of the psyche, and because these symbols take their impetus from the most formative and confused periods of our lives they are often time-sculptures of terrifying ambiguity”. ${ }^{54}$ Not only have Ballard's formative years been spent in the busy and lively wartime Shanghai, he has

\footnotetext{
${ }^{53}$ BAKER. Iterative architecture: a Ballardian text, p. 14.

${ }^{54}$ BALLARD. Time, memory and inner space, p. 200.
} 
always been the owner of an overactive and unique imagination. Autobiographical analyses of Ballard's fiction would reveal them as attempts to externalize the inner world of the psyche (influence of the Surrealists) as informed by his childhood and war experiences. His work would be ciphers to be decoded, and the key, his memories of Shanghai: with his world ripped apart, he plays with the fragments. He used his experiences to show how the collapse of normalcy can be sobering by disclosin Conversations: J. G. Ballard g a differently and somehow more satisfying world. The war probably never ended for Ballard, and it is a good thing he never truly left it, as it has informed his vision and his fiction indelibly. To step outside of Lunghua would be to step outside his own head.

\section{ABSTRACT}

J. G. Ballard's childhood experiences in Shanghai during World War II have indelibly shaped his fiction. Even though war imagery pervade his work, it took him almost forty years to write an autobiographical novel, Empire of the Sun. Echoes of these experiences crop up everywhere in his fiction, to the point a same event is narrated in different stories and books. By looking at one of these iterative events, this article analyzes Ballard's major auto- and semiautobiographical works to elucidate his particular and intriguing mesh of memory and imagination.

\section{KEYWORDS}

War narratives, autobiography, trauma

\section{REFERENCES}

BAKER, Brian. Iterative architecture: a Ballardian text. 21: journal of contemporary and innovative fiction, v. 1, n. 1, 2008/9. <http://www.edgehill.ac.uk/english/ documents/21/issue1/BrianBaker.pdf>. Downloaded on: 20 Apr. 2009.

BALLARD, J. G. The dead time. In: Myths of the near future. London: Triad Granada, 1984. p. 141-168.

BALLARD, J. G. The kindness of women. New York: Farrar, Strauss and Giroux, 1991.

BALLARD, J. G. The atrocity exhibition. London: Harper, 2006.

BALLARD, J. G. Empire of the sun. London: Harper, 2006.

BALLARD, J. G. Introduction. In: __. Crash. London: Harper, 2008. p. 3-6. 
BALLARD, J. G. Miracles of life. London: Harper, 2008.

BALLARD, J. G. Time, memory, and inner space. In: A user's guide to the millennium. New York: Picador, 1996. p. 199-201.

BENYEI, Tamas. White Light: J. G. Ballard's Empire of the sun as a war story. The Anachronist: the literary journal of the Department of English Studies, n. 2.000, p. 249275.

DENTITH, Simon. Parody. London: Routledge, 2000.

GASIOREK, Andrzej. J.G. Ballard. Manchester: Manchester University Press, 2005.

ORAMUS, Dominika. Introduction. In: Grave new world. Warsaw: Warsaw University Press, 2007. p. 3-22.

PUNTER, David. The hidden script: writing and the unconscious. London: Routledge, 1985.

SELF, Will. Conversations: J. G. Ballard. In: . Junk mail. London: Penguin, 1996. p. 79-91. 